\title{
Views on the Cultural Invasion
}

\author{
Yuanyuan Zhang \\ School of Foreign Studies, Zhengzhou University of Industrial Technology, Henan 451100, China. \\ 270933844@qq.com
}

Keywords: cultural invasion, traditional culture, influence, countermeasure.

\begin{abstract}
Cultural invasion is not an unfamiliar word to us now. So, you will find your life full of the foreign culture, and the cultural invasion is around you constantly, therefore, it is reasonable for us to think over the cultural invasion in our country. Under the threat of being substituted by the foreign culture, we must realize the relationship between traditional culture and the world culture is that the culture of a nation belongs to the culture of the world; however, the culture of the world does not belong to the culture of the nation. During a period of time, the national culture must have some outdated factors, in another way, one culture cannot always be the most advanced one, the culture development is a promoting process, especially in the time of informational globalization, mixing together of all the different cultures is the final tendency. Of course, this kind of fixing together needs communication among different cultures; what we should pay more attention is during the process of communication with other cultures; we should not get into the trap of hegemonism and lost in the parochial nationalism. Instead, we should take great advantage of the economic globalization and our getting into the WTO, make good use of the communication system, in order to quicken the pace of broadcasting our traditional culture and widely absorbing the world advanced culture. Only in this way can we reconstruct our great and flourishing culture.
\end{abstract}

\section{Introduction}

"Colonization" was initially used to denote the military, economic, and cultural oppression or domination of one country over another; of which the Christian Crusades in the second century, Genghis Khan's invasion of the Middle East and China in the 13th century, and European invasion of Africa, Asia and the Americas since the 16th century are some widely acknowledged examples. Cultural invasion has always been considered an implicit yet significant integral part of the colonization process.

The term "cultural invasion" was inspired by people in Europe and the United States who began to emphasize the cultural rather than the economic or political domination of the West. Traditionally, the critiques of cultural invasion have been couched in terms of cultural domination of one culture imposing its way of life on another. Thus, the image of the colonial imperialist imposing its political, economic, and cultural agenda on subaltern population is immediately invoked. However, the debate over cultural invasion tends to ignore the inherent nature of culture- vitality, communication, and sharing and mutual interaction. The perspective of "cultural invasion", although circumspect in detecting the cultural oppression imposed by the developed West to the rest of the world, fails to acknowledge the fact that indigenous people in the Third World are active actors in shaping their cultures.

The most salient weakness in the thinking of cultural invasion in previous colonial terms is that it does not reflect the new social reality under globalization anymore. This new form of cultural invasion, stripped from the previous underpinning force of military and political coercion, is now backed up by a unified global economy. This new reality gives the neo-cultural invasion some very interesting features. On the one hand the neo-cultural invasion is closely associated with the unequal global economic power structure and the hegemonic Western discourse of materialism, modern lifestyle and consumption, on the other hand, it grants a greater degree of autonomy and flexibility to the individual actors in the third world compared to the previous colonial age. It is a new form of 
cultural invasion, a cultural invasion that is in accordance and deeply intertwined with the institutional and discursive power of a highly globalize market economy.

China is a country with a history of five thousand years, its profound culture can be a mental power which have great influence on the development and improvement of the society. Nowadays, cultural competency as a kind of important standard to measure the overall national strength and the degree of social civilization of a country is cared more by each country around the world. This kind of transmission of culture is utilized as a way of cultural permeation by some countries, which believe in the hegemonism. Those countries try to do their utmost to sale their concept of value intending to cripple and substitute for other countries' native culture, then extend their tyranny, such as Japan and the U.S. which have already rooted deeply into our Chinese' hearts, however, lots of our native culture have been forgotten. Cultural invasion can be a very proper word to describe this kind of behavior, our Chinese should do something to enhance our culture' world competition force in order to prevent our excellent native culture from being damaged by the cultural invasion.

\section{Definition of Culture}

Before we talk about the cultural invasion, we should know something about culture. Let us briefly overview some definitions of culture in the early work of related studies. In anthropology, culture is an omnibus term designating both the distinctly human forms of adaptation and the distinctive ways in which the different human populations organize their lives on earth. These rules need not be universally or constantly obeyed, but all people recognize them, and they ordinarily operate to limit the range of variation in patterns of belief, communication, values, and social behaviors in that population. Obviously, the bulk of research in the area of intercultural communication concerns itself with the latter. However, it is not easy to draw a clear-cut line between these two types of research, because successful research across cultures must inevitably be accompanied by the systematic analysis of those cultures concerned. It seems indispensable that in studying intercultural communication in-depth and making the research findings a useful property for the future, one first has to have a firm grasp of his or her own culture, and to do so, naturally one has to understand how his or her culture operates on him or her and how the system and him or herself interrelates to one another. In this viewpoint, what Becker termed "the research on the communication process within different cultures" would furnish a basis for the study of intercultural communication.

Harm's uniqueness in his approach is that he, unlike the others, made a distinction between communication and culture. His purpose of this distinction is to explain the last chapter of his small book that deals with intercultural communication in the future where such terms as culture and communication may no longer serve the same meanings as they do today. Without waiting for such a future time, these terms may have to be modified even sooner.

Culture is not a static entity but a continuing process; norms are creatively reaffirmed from day to day in social interaction. People in each cultural group are continuously supporting one another's perspectives, each responding to the others in expected ways. In this sense, "culture is a process of communication". The reference group concept cuts across many basic principles of communication; it may help to explain a different psychological set of people in communicating. The concept clearly is related to self-concept and images of others, and it often suggests "some of the structures which are imposed upon the fluid process of communication".

\section{Display of Some Cultural Invasion}

\subsection{Cultural Invasion on the Catering Industry}

These years, western quick service restaurant can be found every corner of our country, the KFC, the Mcdonald's are so familiar to us, to some extent, the development of those fast food is not some bad, because they have already been an important link of the world culture on the catering industry, and they can be seen all round the world, moreover, Chinese people's preferring to the western food also imply that their living standard have been improving. At the same time, this kind of fast food 
restaurants surely strike against Chinese native catering industry. Take KFC as an example, Kentucky Fried Chicken has been one of the most household international brands in urban China since it opened its first Western-style quick service restaurant in Beijing in 1983 which at present is the largest fried chicken restaurant company in the world, KFC aims China as the most promising market and succeeds in its localization strategies in the huge China market. The most prominent success of KFC in China is not only the outcome of KFC's persistent tenets "quality, service and cleanliness" but also the achievements of its keen perception of cross-cultural marketing and its understanding of Chinese culture.

Beside the business street, pizza shop and the KFC always next to each other, people go to these kinds of quick service restaurants constantly, to contrast with people's going to the western restaurants people seldom go to the traditional Chinese restaurant. However, these traditional Chinese restaurants are much cheaper than those fast food shops. In the Chinese restaurants various kinds of cold dishes and spicy jam are free, it will only take you a little money to have a big meal, but there are still few people.

\subsection{Cultural Invasion on the Festivals}

Once we mention the traditional Chinese festivals, lots of people will talk about the Spring Festival, the Lantern Festival, the Dragon Boat Festival, the Chinese Valentine's Day, the Mid-autumn Day, the Double Nine Festival and other traditional festivals, all these special festivals make us know clearly about the attractiveness and fascination of our traditional culture. The local customs and practices, the religion, the ethics and all the important cultural factors in our daily life are included in these traditional holidays; they are the sediments of the development of our time-honored local history.

It is said that during Lantern Festival in the last year, Korea intended to put this festival into the catalogue of the cultural heritage and asked the United Nations to allow the Lantern Festival as the representative of cultural heritage but were against by most people. This year, before the Lantern Festival, researchers asked some college students about the habitude of the Lantern Festival, it was a pity that almost none of them knew that. People only hold the impression that this day is in memory of $\mathrm{Qu}$ Yuan and on this day, people would eat the sweet dumpling, while they know little about which day is the Lantern Festival, which day is the Ta Qing, and which day does the dragon boat game is taken. To be contrast, many "modern people" are crazy about the Saint Valentine's Day, the Fathers' Day, the Christmas and other western festivals. The arriving of the western festival wavers and blurs our Chinese reorganization of the concept of the word "festival". Letting off firecrackers and eating dumplings on the Spring Festival, enjoying looking at the moon and eating the moon-cake on the Mid-autumn Day, enjoying the festive lantern and guessing the riddles on the Lantern Festival. All these old activities of the local festivals give people a strong impression of the eastern culture, though people show care to each other without garish behavior, give love to each other without arrogant words, it makes tacit agreement between them. A simple wish, a common present leaves a deeply meaning and calls a profound moving. The traditional festivals make a nation together and encourages a nation's imagination.

\subsection{Cultural Invasion on the Entertainment}

When we still hold the impression of Korea like the Korea War and the pickled vegetable, the Korean culture has engulfed the whole Asia at an unbelievable speed. From the inland of China to Japan and from HongKong to Taiwan, people take delight in talking about Korean music, Korean television program, Korean clothing, and even Korean roast and Korean cosmetic. The teenagers, of course, will not lose any chance to become in fashion. They regard themselves as the "fans of the Korean". Students, who like Korean culture, be fond of Korean film and crazy about the Korean pop stars are seen repeatedly.

The film production of the U.S. only takes $5 \%$ of the world total production, but it takes $92.4 \%$ of the world market share. And no one can compete with the U.S. on the music operas, the American film even takes $60 \%$ of the world box office.

The cartoon, caricature and computer games from Japan have become the chief entertainment for almost all the teenagers in our country. The time of listening to the mother's story of native old fables 
and the myth will never go back. Instead of this the Donald Duck, the Jurassic, the transformers and the Harry Potter became the most famous and fashionable words during our everyday life.

\subsection{The Current Situation of Cultural Invasion in China}

Nowadays, culture as a newly rising golden industry has become the most quickly developing industry in the world, and its increasing speed is far more quickly than that of the increasing world economy. The world cultural market maybe divided into four parts: the U.S. takes $42.6 \%$, the European takes 33.9\%, some countries in the Asia and South Pacific Ocean take 19\%, and other countries take $4.5 \%$, while in the $19 \%$, Japan and Korea have already take $13.5 \%$, how many markets are left to China? Before we think about how to occupy the pitiful left market, the television industry, the film industry, the publishing industry, the advertisement industry and the cartoon industry and even the ikebana are aiming to get into the large potential market of China. China is under a dangerous situation.

\section{Influence of the Cultural Invasion}

\subsection{Positive Influence}

If the native culture does not have any communication with other culture, it will be in the isolated situation. It is very dangerous to lose a referent while developing native culture; it is easy for the native culture to be in an obdurate cultural environment. On the other hand, the foreign culture will also take terrifying waves and many great disadvantages on the native culture, and that is where the challenges are.

Globalization fiercely strikes against the native culture, we have been close to the modern society from all aspect of our life. Before we get our culture adjust to the modern world, the fast development of modernization has already made us out-of-date. Why can't we just do something to change this situation? The lovely Santa Claus helps the western people to feel more relax and comfortable while enjoying their spring festival, so why can't we just create a pretty Spring Festival Panda? Use this one of our national treasures to add more fan while we enjoying this one of our most important festivals?

No repel on the foreign culture is one of the characteristics of the culture, and the greatest ability of absorbing and containing other culture is the other one. According to this concept, the foreign culture will do no exactly harm to our native culture, and what we should do is to think serious about how to set our position, how to urge the development of our own culture by absorbing the essence of the outside ones. That is to say, only if we accept the foreign culture and talk with it and fight with it, can we really show the deep essence of our own culture. The human society will never get advanced if there is no communication on the culture among the world.

\subsection{Passive Influence}

The essential meaning of culture is very profound; the form of culture is also a great variety. Culture is the total of mental civilization and physical civilization in a broad sense, and culture can be understanding as the literature, art, education and religion in a narrow sense. Culture is the essential root, which affords a nation or a country to survive and develop, and it is the important sign to differ our nation from others. People from different nation all over the world are proud of their own cultures; a nation can only stand longer in this world if they have their own culture. Many remarkable native cultures and the concepts of value which are bred in these native cultures. Especially after our country got into the WTO, some powerful western country with the U.S. as the leader, strengthen their permeation of their culture into ours, in order to realize their purpose of win our country without a war. Culture is a phenomenon, which has great effect in portraying a complete person and only exists in human society; its influence is unconsciously and constantly. A good cultural environment can do a lot to help cultivate a healthy personality, which is consented by the dominant culture or the leading culture; in the opposite, the outside gray culture certainly will unconsciously do harm to the cultivation of a healthy personality.

Along with the inrush of the western woods, all kinds of rotten and degenerative ideas are also in pouring. The phenomenon of confraternity, violence, superstition, eroticism, the concept of putting profit first and the lost of social credit can be found everywhere in our society. What we saw is not 
people's painstaking working like before, but the heavy traffic in front of the high-ranking hotel; what we heard is not the swearing of being loyal to our nation, but the so-called if you have money you will have the future, if you have the benefit you will make your dream come true. This is just the reason why these kinds of crime keep increasing. While People consume the western culture, they lost their dignity and pursuing of their dreams simultaneously.

\section{Countermeasures to the Cultural Invasion}

\subsection{Stresses on the Chinese}

As for preventing the cultural invasion continually occurs in China, we should pay more attention to the studying of Chinese. As Chinese is one of the most ancient languages in the world, and it is used by most of the people among the world, however, with the development of globalization and the entrance of the WTO, more and more people aware the importance of English, instead of studying our native language, numerous people go to the studying agency like the New Oriental, the Da Shan Foreign Language School to study English, and the parents would like to pay half of their salary to find their children a tutor to help them to study English. Now, the fast pace of working and studying make many people even have no time to have a date with their girlfriends or boyfriends, but they will extrude some time to improve their English, however, no one had ever thought about the influence of English on our native language. The invasion of English to Chinese should be a serious problem we have to stress on.

In order to make people pay more attention to our native language, we should let people know the importance of Chinese. The sociologist said that all the cultures are special, and they are different from each other, and all the languages, as a part of culture, are also special from each other. According to the sociologist we find that language can be a part of our traditional culture, it is firstly and mostly used by our local people, so if one day our local people do not like to use it, it will face the fate of dying out, that can be a lost of our traditional culture. To our Chinese, our native language has done a lot to the development of our country, the same language also makes it possible for people from different areas of China to interchange ideas.

The native language to its country is one of its most precious treasures, for our Chinese, the native language is one of the most important parts of our traditional culture. To some extent, Chinese can be the soul of the characteristic of our nation. So, we must protect it from the invasion of other language, especially English.

\subsection{Countermeasures that the Young People Should Take}

For the school part, the administrators can organize students to visit some museums to see our old mysterious civilization, or they can just go to the zoo, out of question, everyone will be shocked by thinking of there are so many animals in our country, and the most marvelous thing is that we live together in a world, in China! All these activities will leave a deep impression in our young people's mind; they will deeply understand our excellent culture.

The government can set up some organizations to propagandize our culture. So many remarkable traditional craft become extinct, that is not only because seldom people are concerned about them, but also because they almost have no chance to know something of them. So, it is necessary for the government to do something to change this situation. They can hold an exhibition of ceramics or hold a competition on the geography; they can invite some excellent experts in their aspect to give people a lecture on TV.

The legislative and the promotion department should pay special attention to the passive influence of the western music, American film, Japanese caricature and cartoon, and also the on-line games. Moreover, they have to balance the social benefit of culture and the economic benefit of culture; do not only put their eyes on the economic benefit. In the end, they have to enhance their research on the policy of communicating between different cultures and make necessary efforts to keep the westernized strategy away from us. 


\subsection{Countermeasures that the Whole Society and the Whole Country Will Take}

The world culture consists of different culture of different nations and different countries. Culture belongs to the nations, it has its own characteristic, and it is the evidence of a nation's existence. Culture also belongs to the world, it has the general regularity of existence and development, and it is the achievement of all human intelligence. Many foreigners know the porcelain, china, calligraphy and carving in China. The aged bronze vessel of China is placed in the office of the president of France. It is clearly proved that only the culture of the nation is the most beautiful and active one.

Developing our traditional culture asks us to get rid of the old and meaningless culture and absorb the good and newly rising culture based on propagating our excellent traditional culture. Each culture of each nation will have its shining point and also the blot, so it asks our whole society and our whole country to select some useful culture, which is helpful to develop our own culture. Some great western culture maybe does a lot to promote their culture, but will do nothing but harm to our culture, this kind of culture can be called the excellent culture but not suit for us, such as the Christmas, it is meaningful to each westerner, but for us, we should just treat it as a simple western festival, knowing it is enough, because we have our own Spring Festival, how can we have concerned nothing about our own Spring Festival while crazy about theirs.

And for some western culture, as a whole they will do harm to our people, but if we separate them into several parts, we will see something useful. Also take Christmas as an example, as a whole it is one of the most important festivals in the western, and this important western festival has nothing to do with our culture, but if we only see part of it, like the enthusiastic atmosphere during the whole Christmas, that can be something useful to us, we can learn how to encourage people in our country to be zealous during our Spring Festival.

\section{Summary}

Under the threat of being substituted by the foreign culture, we must realize the relationship between traditional culture and the world culture is that the culture of a nation belongs to the culture of the world; however, the culture of the world does not belong to the culture of the nation. During a period of time, the national culture must have some outdated factors, in another way, one culture can not always be the most advanced one, the culture development is a promoting process, especially in the time of informational globalization, mixing together of all the different cultures is the final tendency. Of course, this kind of fixing together needs communication among different cultures, what we should pay more attention is during the process of communication with other cultures, we should not get into the trap of hegemonism and lost in the parochial nationalism.

During the process of developing our traditional culture, we should also concern more about the effect of creation. We have to create a special way to develop our national culture. In my mind, our special way of developing traditional culture is developing our culture by absorbing part of foreign advanced cultures, not totally but partially, just add some useful parts into our culture, which we have to correctly pick out from the foreign culture. In this way, we can either advance our traditional culture, or protect it from the threat of the foreign culture. However, during this process there are still many problems we should solve, and my paper cannot cover all of them. On the way of developing our culture, we are just on the primary stage, which means we still have a long way to go.

\section{References}

[1]. Rogers, Everett M. and Shoemaker, Floyd F, Communication of Innovation: A Cross Cultural Approach[M], New York: The Free Press, 1971, p.70-76.

[2]. Harms, L.S, the Intercultural Communication[M], New York: Harper, 1973, p.27-34.

[3]. Hall, Edward, T, Beyond Culture [M], New York: Harper, 1973, p.17-23. 
[4]. Christopher, Buckley, Culture and Privilege in Capitalist Asia[M]. University of Chicago Press, 1999, p.208-229.

[5]. John, Toms, Globalization and Culture[M], Nanjing: University of Nanjing Press, 2002, p.128-188. 